\title{
Fanconi-Associated Nuclease 1
}

National Cancer Institute

\section{Source}

National Cancer Institute. Fanconi-Associated Nuclease 1. NCI Thesaurus. Code C92484.

Fanconi-associated nuclease 1 (1017 aa, $\sim 114 \mathrm{kDa}$ ) is encoded by the human FAN1 gene.

This protein is involved in DNA damage repair. 